\title{
The effect of intragastric infusion of glucose, lipids or acetate on fasting nitrogen excretion and blood metabolites in sheep
}

\author{
BY J. M. ASPLUND*†, E. R. ØRSKOV $\ddagger$, F. D. DEB. HOVELL \\ AND N. A. MACLEOD \\ Rowett Research Institute, Bucksburn, Aberdeen AB2 9SB
}

(Received 17 January 1985 - Accepted 26 February 1985)

\begin{abstract}
1. Two experiments are reported in which the effect of the intragastric infusion of non-protein energy on fasting nitrogen losses was studied. Expt 1 was a preliminary trial with two $35 \mathrm{~kg}$ lambs given $0,144,288$ or $432 \mathrm{~kJ} / \mathrm{kg}$ live weight $(W)^{0.75}$ per $d$ as lipid or glucose infused into the abomasum for periods of $3 \mathrm{~d}$. Expt 2 was of a $4 \times 4$ Latin square design with four sheep of about $30 \mathrm{~kg}$ live weight. The four treatments were control (fasted with water infusion), or the infusion of $144 \mathrm{~kJ} / \mathrm{kg} \mathrm{W}^{0.75}$ per $\mathrm{d}$ as glucose or lipid into the abomasum or as acetic acid into the reticulo-rumen.

2. Compared with the fasted control, glucose infusion reduced $(P<0.05) \mathrm{N}$ excretion to about 0.6 of that of the control, increased $(P<0.05)$ plasma glucose, decreased $(P<0.05)$ plasma urea and $\beta$-hydroxybutyrate, and was without effect on plasma amino- $\mathrm{N}$ or creatinine excretion.

3. Lipid and acetate infusions were without statistically significant effect on $\mathbf{N}$ or creatinine excretion or any of the blood indices measured, with the exception of plasma glucose which was reduced $(P<0.05)$ with acetate infusion.
\end{abstract}

The so-called 'nitrogen-sparing' effect of carbohydrates has been recognized for some years. With non-ruminant animals, the feeding of increments of carbohydrate to fasting animals, or to animals with low energy intakes, usually result in a decrease in $\mathbf{N}$ excretion (Munro, 1964). It has been generally assumed that the reason for this was that the glucose replaced some protein as a source of energy and, in particular, as a precursor of the hexose (acting as a pyruvate precursor for the maintenance of the tricarboxylic acid cycle) presumed to be required for the utilization of body fat. However, the mechanisms whereby this is achieved are still a subject for debate (Flatt \& Blackburn, 1974). Dietary fat is not generally considered to have a $\mathrm{N}$-sparing effect, but recent observations (Radermacher et al. 1982) suggest that it may, in fact, reduce $\mathbf{N}$ excretion under some conditions.

Very few observations have been made using ruminant animals. In studies with sheep nourished by intragastric infusion, it was observed that $\mathrm{N}$ excretion and plasma $\beta$ hydroxybutyric acid $(\beta$-OHB) levels were reduced when glucose was infused into animals receiving no protein $(\mathrm{Ku}$ Vera, 1983). Thus it would appear that ruminants respond to increments of carbohydrate in a manner similar to non-ruminant animals. It has also been shown that individual volatile fatty acids (VFA) influence $\mathrm{N}$ excretion in ruminants. Propionic acid, a glucogenic energy source, reduced $\mathrm{N}$ excretion while acetic acid alone increased N loss (Armstrong \& Blaxter, 1957; Ørskov et al. 1979a). Nothing is known about the influence of triglyceride on $\mathrm{N}$ excretion in ruminants (Agricultural Research Council, 1980). Since triglyceride is a potential source of both glucogenic and ketogenic components, it is of interest to know if energy from dietary fat has a similar or different influence on $\mathrm{N}$ retention when compared with other energy sources.

* Present address: Department of Animal Science, University of Missouri, Columbia, USA.

$\uparrow$ Kemin Industries International Fellow.

$\ddagger$ For reprints. 


\section{MATERIALS AND METHODS}

\section{Treatments and design}

Two experiments were conducted and in both total nourishment of the sheep was by intragastric infusion. A preliminary trial, Expt 1, employed a cross-over design with two sheep to study the effect of fat or glucose infused into the abomasum on the excretion of $\mathrm{N}$ in animals receiving no protein. The amount of glucose or lipid infused was varied so as to supply no energy (water infused), or about 144,288 or $432 \mathrm{~kJ} / \mathrm{kg}$ live weight (W) ${ }^{0 \cdot 75}$ in four successive $3 \mathrm{~d}$ sub-periods. Each experimental main period was thus of $12 \mathrm{~d}$ during which either fat or glucose was infused. One sheep received fat and the other glucose during the first period, and the energy sources were then reversed for the second period which followed a recovery period of $14 \mathrm{~d}$, during which the animals were repleted with infusion of VFA, glucose and casein at 1.5 times maintenance levels.

Expt 2 was conducted to compare the effect of glucose, fat or acetate, which were infused so as to provide $144 \mathrm{~kJ} / \mathrm{kg} \mathrm{W}^{0 \cdot 75}$, with the infusion of water for one period as an energy-free control. The design was a $4 \times 4$ Latin square with four sheep. Each of the four treatments was administered for $3 \mathrm{~d}$. Acetate was infused into the rumen, and lipid and glucose into the abomasum.

\section{Animals and management}

Castrated male sheep, 30-35 kg live weight, were fitted with permanent rumen cannulas and abomasal catheters at least 4 weeks before the experiments began. A minimum of 2 weeks' adaptation to infusion (above energy and $\mathbf{N}$ equilibrium) was allowed. Infusion was by the intragastric method as described by Ørskov $e t a l$. (1979 b) with VFA and buffer infused into the rumen, and glucose, casein or fat-solution emulsions infused into the abomasum. The volumes infused into the rumen and abomasum were kept constant with water, minerals and (diluted) buffer being infused into the rumen when no VFA was given, and water only into the abomasum when no glucose or fat was given. Total volumes were about $0 \cdot 8-1 \cdot 0$ litres $/ \mathrm{kg} \mathrm{W}^{0 \cdot 75}$ per $\mathrm{d}$, greater than originally described (Ørskov et al. $1979 \mathrm{~b}$ ). Vitamins and trace minerals were administered daily via the abomasal catheter to all sheep.

Lipid emulsions were prepared as homogenates containing $200 \mathrm{~g} / \mathrm{kg}$ as a mixture of 750 parts lard and 250 parts groundnut oil. This was stabilized with soya-bean lecithin and glycerol monostearate, each at $50 \mathrm{~g} / \mathrm{kg}$ fat. The lecithin was homogenized in hot water and the glycerol monostearate was melted with the lard and oil. The melted mixture was added gradually to hot water and blended using a bench homogenizer (Ystral; BallrechtenDottingen, W. Germany). This (unstable) emulsion was then passed several times through an industrial homogenizer (Weir Pumps Ltd, Cathcart Works, Glasgow). Each daily lipid ration was prepared from this stock emulsion by further dilution to a total of $2.8 \mathrm{~kg}$ with cold water immediately before each daily infusion. These diluted emulsions were stable for the $24 \mathrm{~h}$ infusion. For Expt 2, only glycerol monosterate was used at a level of $75 \mathrm{~g} / \mathrm{kg}$.

\section{Sampling and analysis}

Urine was collected in vessels containing about $300 \mathrm{ml}$ diluted sulphuric acid $(100 \mathrm{ml} / 1)$. It was weighed and sampled daily, and analysed for total $\mathrm{N}$ by the method of Davidson et al. (1970) and for creatinine by the method of Hawk et al. (1947). Blood was obtained by venipuncture on the last day of each $3 \mathrm{~d}$ infusion. Plasma was collected and stored at about $-20^{\circ}$ until needed. Plasma samples were analysed for glucose by the method of Trinder (1969), $\beta$-OHB by the method of Zivin \& Snarr (1973), urea by the method of Marsh et al. (1965) and free amino-N by the method of Palmer \& Peters (1969). The results presented represent the mean of the last $2 \mathrm{~d}$ of each $3 \mathrm{~d}$ period (urine), or the last day of each period (plasma). 
Table 1. Expt 1. Effect of lipid or glucose infusion on nitrogen excretion and plasma glucose and $\beta$-hydroxybutyrate $(\beta-O H B)$ of protein-deprived sheep of about $35 \mathrm{~kg}$ live weight $(W)$

\begin{tabular}{|c|c|c|c|c|c|c|}
\hline \multirow{2}{*}{$\begin{array}{l}\text { Level of infusion } \\
\left(\mathrm{kJ} / \mathrm{kg} \mathrm{W}^{0.75} \text { per } \mathrm{d}\right)\end{array}$} & \multicolumn{2}{|c|}{$\begin{array}{l}N \text { excretion } \\
(\mathrm{g} / \mathrm{d})\end{array}$} & \multicolumn{2}{|c|}{$\begin{array}{l}\text { Plasma glucose } \\
\text { (mg/l) }\end{array}$} & \multicolumn{2}{|c|}{$\begin{array}{l}\text { Plasma } \beta \text {-OHB } \\
(\mathrm{mmol} / \mathrm{l})\end{array}$} \\
\hline & Lipid & Glucose & Lipid & Glucose & Lipid & Glucose \\
\hline 0 & $7 \cdot 90$ & 8.92 & 640 & 420 & 1.42 & 1.15 \\
\hline 144 & 7.64 & 4.44 & 500 & 540 & $1 \cdot 19$ & 0.54 \\
\hline 288 & 5.08 & 5.73 & 550 & 810 & $2 \cdot 21$ & $0 \cdot 16$ \\
\hline 432 & $5 \cdot 42$ & 4.91 & 700 & 900 & 2.80 & 0.06 \\
\hline
\end{tabular}

Table 2. Expt. 2. Effect of lipid, glucose or acetate infusion (144 $\left.\mathrm{kJ} / \mathrm{kg} \mathrm{W}^{0 \cdot 75} \mathrm{per} d\right)$ on nitrogen excretion and blood measurements of protein-deprived sheep of about $30 \mathrm{~kg}$ live weight $(\mathrm{W})$

\begin{tabular}{lccccc}
\hline \hline & \multicolumn{5}{c}{ Infusion regimen } \\
\cline { 2 - 6 } & Glucose & Lipid & Acetate & Water & SED (6 df) \\
\hline N excretion (g/d) & $3 \cdot 85^{\mathrm{a}}$ & $5 \cdot 43^{\mathrm{b}}$ & $5 \cdot 47^{\mathrm{b}}$ & $6 \cdot 29^{\mathrm{b}}$ & 0.88 \\
Creatinine excretion (g/d) & $0 \cdot 64$ & $0 \cdot 65$ & $0 \cdot 67$ & $0 \cdot 67$ & $0 \cdot 02$ \\
Plasma glucose (mg/l) & $620^{\mathrm{a}}$ & $50^{\mathrm{b}}$ & $440^{\mathrm{c}}$ & $510^{\mathrm{b}}$ & 29 \\
Plasma $\beta$-hydroxybutyrate & $0 \cdot 3^{\mathrm{a}}$ & $1 \cdot 7^{\mathrm{b}}$ & $2 \cdot 1^{\mathrm{b}}$ & $1 \cdot 6^{\mathrm{b}}$ & $0 \cdot 34$ \\
(mmol/l) & 41 & 38 & 39 & 36 & $4 \cdot 2$ \\
Plasma free amino-N (mg/l) & $100^{\mathrm{a}}$ & $145^{\mathrm{b}}$ & $137^{\mathrm{b}}$ & $169^{\mathrm{b}}$ & $15 \cdot 1$ \\
Plasma urea-N (mg/l) & & & & \\
\hline \hline
\end{tabular}

a, b, c Means with a different superscript letter were significantly different $(P<0.05)$.

\section{RESULTS}

Glucose infusion

The infusion of glucose reduced $\mathrm{N}$ excretion in both experiments. In Expt 1 (Table 1) the $\mathrm{N}$ loss was reduced to $0.50,0.64$ and 0.55 of that of the totally-fasted control (loss equivalent to about $600 \mathrm{mg} / \mathrm{kg} \mathrm{W}^{0 \cdot 75}$ per d) as the level of glucose infused was increased. In Expt 2, where statistical tests could be applied, the infusion of $144 \mathrm{~kJ} / \mathrm{kg} \mathrm{W}^{0.75}$ per $\mathrm{d}$ as glucose (similar to the lowest level used in Expt 1) reduced $N$ excretion to 0.61 of that of the fasted control $(P<0.05)$ (Table 2), whose excretion was equivalent to about $500 \mathrm{mg} / \mathrm{kg} \mathrm{W}^{0.75}$ per $\mathrm{d}$. The reduction in $\mathrm{N}$ excretion caused by the infusion of glucose, when expressed as a proportion of fasting $\mathrm{N}$ loss, was thus in good agreement between the two experiments.

The infusion of glucose was without effect on creatinine excretion. Plasma glucose levels were raised and $\beta$-OHB was reduced in both experiments (Tables 1 and 2), the effect being significant $(P<0.05)$ in Expt 2 . Plasma urea was reduced $(P<0.05)$, but there was no effect on plasma amino- $\mathrm{N}$ in Expt 2 (Table 2).

\section{Lipid and acetic acid infusion}

The infusion of lipid was without statistically significant effect on $\mathrm{N}$ or creatinine excretion, or on any of the blood indices measured (Table 2). Similarly, the infusion of acetate was without effect, with the exception of plasma glucose levels with were reduced $(P<0.05)$ (Table 2). 


\section{Discussion}

The effect of glucose

The reduction in $\mathrm{N}$ excretion associated with the effect of glucose was very similar to other observations in our laboratory with infused sheep. Ku Vera (1983) infused lambs with 0 , 80,160 or $260 \mathrm{~g} / \mathrm{d}$ as glucose, equivalent to $0,90,180$ or $300 \mathrm{~kJ} / \mathrm{kg} \mathrm{W}^{0 \cdot 75}$ per d (no protein or other energy-yielding nutrients were infused). Glucose infusion reduced $\mathrm{N}$ excretion to $0.70,0.57$ and 0.55 of that of the fasted control (loss 570 (SE 24) mg/kg W0.75 per d) for the three levels of glucose infusion respectively. Ku Vera (1983) imposed his glucose treatments both by progressively increasing, or by progressively decreasing the amount of glucose infused. The effect was the same with both regimens and therefore could not be attributed to a time-effect associated with adaptation to $\mathrm{N}$-free alimentation. Similarly, there was no evidence of adaptation (as a reduction of $N$ excretion with time) by sheep given about $450 \mathrm{~kJ} / \mathrm{kg} \mathrm{W}^{\mathbf{0} 75}$ per d as an intrarumen infusion of a mixture of VFA but no protein (Hovell et al. $1983 \mathrm{a}$ ). Infused nutrients are made available to absorption sites almost instantaneously and, therefore, adaptation will be more rapid than with normally-fed animals. This rapid stabilization by ruminants nourished by intragastric infusion is in contrast to the work with normally fed non-ruminants cited by Munro (1964), in which adaptation to N-free diets took several days before $\mathrm{N}$ excretion was stabilized. The cattle used by Ørskov et al. (1983) showed no evidence of a time effect with fasts of 4-5d (E. R. Ørskov, N. A. MacLeod, S. T. M. Fahmy, L. Istasse and F. D. DeB. Hovell, unpublished results). Sheep nourished by intragastric infusion stabilized within the first day of a $5 \mathrm{~d}$ period when changes in energy of up to about 0.2 maintenance were made (Hovell et al. 1983 b). Tao \& Asplund (1975) and Wolfrom \& Asplund (1979) reported that there were no residual effects when periods of $3 \mathrm{~d}$ were used with sheep given intravenous infusions. With the $3 \mathrm{~d}$ periods used in the present experiments, the conclusions were not altered if the first day of each period were included in the analysis of the results.

The reduction in urinary $\mathbf{N}$ losses associated with glucose infusion is similar to that reported from experiments with non-ruminant animals (Munro, 1964). With ruminants, Armstrong \& Blaxter (1957) and Armstrong et al. (1957) reported that fasting sheep reduced $\mathrm{N}$ excretion when infused with propionic acid. Eskeland et al. $(1973,1974)$ reported the intravenous infusion of glucose or propionic acid to promote higher $\mathbf{N}$ retention in fed sheep than acetic or butyric acids. However, Ørskov et al. (1979a) were unable to demonstrate differences in the $\mathrm{N}$ retention of sheep entirely nourished by the intragastric infusion of casein and VFA, when the contribution of propionic acid ranged from 150 to $450 \mathrm{mmol} / \mathrm{mol}$ VFA infused. Greater extremes ( 50 or $550 \mathrm{mmol} / \mathrm{mol} \mathrm{VFA}$ infused) gave a lower $\mathrm{N}$ retention at the low level of propionate (high acetate), and greater $\mathrm{N}$ retention at the high level of propionate.

Thus, although it appears that glucose or glucose precursors reduce the catabolism of body protein in fasted, and possibly increase the utilization of dietary protein in fed sheep, it is not clear whether the mechanism by which these effects are achieved is the same in both fed and fasted animals. Armstrong \& Blaxter (1957) suggested that the necessity for glucose or glucose precursors in fasting animals was to provide sufficient oxalacetic acid to maintain the normal functioning of the tricarboxylic acid cycle. With the provision of greater amounts of glucose or glucose precursor, and with animals receiving protein, any response may be mediated through the endocrine systems, and Munro (1964) and Bergen (1979) have discussed the role of insulin. Flatt \& Blackburn (1974) however, suggested that in the fasting animal, an insulin response may also inhibit lipolysis, and part of any supply of exogenous glucose may therefore be utilized to replace body fat rather than spare gluconeogenesis from body protein. 


\section{The effect of lipid}

Although there was no statistically significant effect of lipid infusion, the results do suggest that there may have been a reduction in $\mathbf{N}$ loss. In Expt 1 (Table 1), with the infusion of $432 \mathrm{~kJ} / \mathrm{kg} \mathrm{W}^{0.75}$ per $\mathrm{d}$ as lipid, $\mathrm{N}$ excretion was reduced to about 0.8 of that of the fasted control. Recently Radermacher et al. (1982) showed that humans infused with a lipid emulsion reduced $\mathrm{N}$ excretion. Munro (1964) concluded that, with the rat, some reduction of urinary $\mathrm{N}$ occurred when fat was fed to the fasting animal, but that carbohydrate had a much greater effect. Certainly we did not observe any transitory rise in $\mathrm{N}$ loss as reported by some workers and discussed by Munro (1964).

Both lipid and normal mixtures of VFA provide potential glucose precursors (glycerol and propionic acid). Armstrong \& Blaxter (1957) reported that the infusion into fasting sheep of a mixture which contained only $60 \mathrm{mmol}$ propionic acid/mol VFA, and which would have contributed about $0.18 \mathrm{~mol}$ propionic acid (to sheep of between 50 and $60 \mathrm{~kg}$ live weight), reduced $\mathrm{N}$ loss. This amount compares with the potential contribution of about $0.2 \mathrm{~mol}$ glycerol from lipid at the highest level of infusion in Expt 1.

\section{The effect of acetate}

Armstrong \& Blaxter (1957) and Armstrong et al. (1957) reported the infusion of acetate alone to increase $\mathrm{N}$ loss to about that of the fasted animal, although the effect was not always statistically significant. There was no increase in $\mathrm{N}$ excretion when acetate was infused in the experiment reported here; indeed, there was a decrease (not statistically significant) (Table 2). It is not clear why our observations should differ from those of Armstrong and his colleagues (Armstrong \& Blaxter, 1957; Armstrong et al. 1957). The amounts infused by ourselves were similar, as was the period of infusion. The rumen $\mathrm{pH}$ of the sheep of Armstrong \& Blaxter (1957) fell below 0.5 which, in our experience, is low if a stable rumen $\mathrm{pH}$ and osmotic pressure are to be maintained with continuous infusion. Therefore one difference may have been that our animals in the experiments reported here were more stable and less stressed. The fact that blood glucose fell (Table 2) may have been an indication that any better stability in our animals was postponing rather than averting hypoglycaemia and that, had we continued acetate infusion, our animals would have showed an enhanced $\mathrm{N}$ loss.

\section{Fasting and basal $N$ losses}

Previous work at this laboratory has shown that the infusion of about $450 \mathrm{~kJ} / \mathrm{kg} \mathrm{W}^{0.75}$ per $\mathrm{d}$ as VFA into fasting cattle reduced $\mathrm{N}$ losses to 0.75 (dairy cows) and 0.54 (steers) of fasting $\mathrm{N}$ losses (Ørskov et al. 1983). This reduction of fasting $\mathrm{N}$ loss to basal $\mathrm{N}$ loss is comparable with the reduction to between 0.50 and 0.64 of fasting $N$ loss resulting from the infusion of glucose in the experiments reported here. Similarly, calculation from the results of Fuller \& Crofts (1977) gave the maximal reduction of fasting $\mathrm{N}$ loss in pigs given $100 \mathrm{~g}$ starch $/ \mathrm{kg}$ $\mathrm{W}^{0.75}$ to be 0.58 of fasting $\mathrm{N}$ loss (endogenous $\mathrm{N}$ losses were taken to be urine losses plus the increment in faecal loss associated with the feeding of starch).

The amount of glucose potentially available to a fasting lamb may be calculated with the assumption of gluconeogenesis from body protein of $570 \mathrm{~g} / \mathrm{kg}$ protein (Krebs, 1964) and energy values of protein and fat at 23 and $39 \mathrm{~kJ} / \mathrm{g}$ respectively (Agricultural Research Council, 1980). With a basal $\mathrm{N}$ loss of $350 \mathrm{mg} / \mathrm{kg} \mathrm{W}^{0.75}$ per d (Agricultural Research Council, 1984), taken to be 0.6 fasting $\mathrm{N}$ loss (i.e. $580 \mathrm{mg} \mathrm{N} / \mathrm{kg} \mathrm{W}^{0.75}$ per d); and fasting metabolism as $300 \mathrm{~kJ} / \mathrm{kg} \mathrm{W}^{0.75}$ per d (Agricultural Research Council, 1984), a fasting $35 \mathrm{~kg}$ lamb would have precursors for about $39 \mathrm{~g}$ glucose daily. This compares well with estimates of turnover of 40-60 g daily in slightly larger sheep (Bergman, 1973; Weekes, 1979). About 
$29 \mathrm{~g}$ of this $39 \mathrm{~g}$ is attributable to synthesis from protein. The difference between fasting and basal $\mathrm{N}$ losses is then equivalent to about $12 \mathrm{~g}$ glucose $(0.07 \mathrm{~mol}$ in total, or $13 \mathrm{~kJ} / \mathrm{kg}$ $\mathrm{W}^{0.75}$ per d).

Thus the protein catabolism spared by the infusion of more than $100 \mathrm{~g}$ glucose daily in the present study and that of Ku Vera (1983), spared protein catabolism by an amount equivalent to 12-15 g glucose. The estimations of basal $\mathrm{N}$ loss of cattle (Ørskov et al. 1983) and sheep (Hovell et al. 1983a) when infused with VFA sufficient to supply $450 \mathrm{~kJ} / \mathrm{kg} \mathrm{W}^{0.75}$ per $\mathrm{d}$ would have provided the equivalent of $100 \mathrm{~g}$ glucose daily to a $30 \mathrm{~kg}$ lamb with (presumably) a similar sparing of protein catabolism. Since the provision of substantial amounts of glucose or potential glucose precursor only reduce fasting $\mathbf{N}$ losses by about 0.4 in both ruminants and non-ruminants, the implication is that, with both types of animal, the major part of fasting $\mathbf{N}$ losses are not due to a specific requirement for glucose precursors.

The authors are grateful to $\mathrm{Mr} \mathrm{C}$. Simpson for help with the preparation of the animals, to Mr D. Kyle for help with the execution of the trials and to Mr R. Smart and Miss M. Annand and their colleagues for the chemical analysis.

\section{REFERENCES}

Agricultural Research Council (1980). The Nutrient Requirements of Ruminant Livestock. Farnham Royal, Slough: Commonwealth Agricultural Bureaux.

Agricultural Research Council (1984). The Nutrient Requirements of Ruminant Livestock, Suppl. no. 1. Farnham Royal, Slough: Commonwealth Agricultural Bureaux.

Armstrong, D. G. \& Blaxter, K. L. (1957). British Journal of Nutrition 11, 247-272.

Armstrong, D. G., Blaxter, K. L. \& Graham, N. McC. (1957). British Journal of Nutrition 11, 392-408.

Bergen, W. G. (1979). In Digestive Physiology and Nutrition of Ruminants, vol. 2, pp. 430-431 [D. C. Church, editor]. Oregon: $O$. and B. Books.

Bergman, E. N. (1973). Cornell Veterinarian 63, 341-382.

Davidson, J., Mathieson, J. \& Boyne, A. W. (1970). Analyst, London 95, 181-193.

Eskeland, B., Pfander, W. H. \& Preston, R. L. (1973). British Journal of Nutrition 29, 347-355.

Eskeland, B., Pfander, W. H. \& Preston, R. L. (1974). British Journal of Nutrition 32, 201-211.

Flatt, J. P. \& Blackburn, G. L. (1974). American Journal of Clinical Nutrition 27, 175-187.

Fuller, M. F. \& Crofts, M. (1977). British Journal of Nutrition 38, 479-488.

Hawk, A. B., Oser, B. L. \& Summerson, W. H. (1947). Practical Physiological Chemistry. San Francisco: McGraw Hill.

Hovell, F. D. DeB., Ørskov, E. R., Grubb, D. A. \& MacLeod, N. A. (1983a). British Journal of Nutrition 50, 173-187.

Hovell, F. D. DeB., Ørskov, E. R., MacLeod, N. A. \& McDonald, I. (1983b). British Journal of Nutrition 50, 331-343.

Krebs, H. A. (1964). In Mammatian Protein Metabolism, vol. 1, pp. 125-176 [H. N. Monro and J. B. Allison, editors]. New York and London: Academic Press.

$\mathrm{Ku}$ Vera, J. C. (1983). Mechanisms of the nitrogen-sparing effect of glucose in fasting sheep. MSc Thesis, University of Aberdeen.

Marsh, W. H., Fingerhut, B. \& Miller, H. (1965). Clinical Chemistry 11, 624-627.

Munro, H. N. (1964). In Mammalian Protein Metabolism, vol. 1, pp. 382-482 [H. N. Munro and J. B. Allison, editors]. New York and London: Academic Press.

Ørskov, E. R., Grubb, D. A., Smith, J. S., Webster, A. J. F. \& Corrigall, W. (1979 a). British Journal of Nutrition 41, 541-551.

Ørskov, E. R., Grubb, D. A., Wenham, G. \& Corrigall, W. (1979b). British Journal of Nutrition 41, 553-558.

Ørskov, E. R., MacLeod, N. A., Fahmy, S. T. M., Istasse, L. \& Hovell, F. D. DeB (1983). British Journal of Nutrition 50, 99-107.

Palmer, D. W. \& Peters, T. Jr (1969). Clinical Chemistry 15, 891-901.

Radermacher, P., Grote, H., Herbertz, L. \& Reinauer, H. (1982). Infusionstherapie und Klinische Ernahrung 9 , 279-285.

Tao, R. C. \& Asplund, J. M. (1975). Journal of Animal Science 41, 1653-1659. 
Trinder, P. (1969). Annals of Clinical Biochemistry 6, 24-27.

Weekes, T. E. C. (1979). In Digestive Physiology and Nutrition of Ruminants, vol. 2, pp. 187-207 [D. C. Church, editor]. Oregon: O and B Books.

Wolfrom, G. W. \& Asplund, J. M. (1979). Journal of Animal Science 49, 752-763.

Zivin, J. A. \& Snarr, J. R. (1973). Analytical Biochemistry 52, 456-461. 